\title{
Export led growth hypothesis: Evidence from Kenya
}

\author{
Grace Muhoro ${ }^{1}$, Manaseh Otieno ${ }^{2}$ \\ ${ }^{1}$ Kenya Institute for Public Policy Research and Analysis, Young Professional: Private Sector Development Division, Nairobi, Kenya \\ ${ }^{2}$ Kenya Institute for Public Policy Research and Analysis, Policy Analyst: Trade and Foreign Policy Division, Nairobi, Kenya
}

\section{Email address:}

gracawangu@yahoo.com (G. Muhoro), manaseh.otieno31@gmail.com (M. Otieno)

\section{To cite this article:}

Grace Muhoro, Manaseh Otieno. Export Led Growth Hypothesis: Evidence from Kenya. Journal of World Economic Research. Vol. 3, No. 4, 2014, pp. 37-46. doi: 10.11648/j.jwer.20140304.11

\begin{abstract}
The Export-Led Growth Hypothesis (ELGH) postulates that export growth is one of the key determinants of economic growth. This paper aims to investigate the Export-Led Growth Hypothesis in Kenya using annual time series data from 1976 to 2011 and dynamic time series techniques of Auto Regressive Distributed Lag and 2-Stage Least Squares. The 2-Stage Least Squares is used to correct for the endogeneity problem of the variables involved. A seven-variable Vector Auto Regression (VAR) model (GDP, Exports, Imports, Household Consumption, Government Consumption, Gross Fixed Capital Formation and Foreign Direct Investment) is developed from a national income identity that links output to its contributing factors. The results indicate that there is unidirectional causality running from exports to economic growth. This implies that export-led growth hypothesis can be supported in the Kenyan economy in the short run. Besides, our results suggest that the growth rate of household consumption and Gross Fixed Capital Formation have positive and statistically significant impacts on economic growth. Hence, in the case of Kenya, export enhancing policies that will improve the quantity, quality and value of exports in the overall GDP contribution of exports are recommended in promoting and sustaining economic growth.
\end{abstract}

Keywords: Economic Growth, Export-Led Growth Hypothesis, Causality

\section{Introduction}

Economic growth is a major concern for many countries in the world. Both developing and developed nations are keen to achieving and sustaining high-level growth rates of their output through use of different economic policies. Increasing a country's output has the potential of attracting resources that are needed to drive other economic activities like investments in key sectors hence uplift the people's living standards. One such strategy that a country can explore is increasing its exports.

Past investigations on the potential of exports to increase the growth of output have produced varied results raising several important questions: Do exports contribute positively to growth of output? Are there other factors that have a statistically significant impact on growth of output? Does Kenyan data support the export led growth hypothesis?

Export activities fuel growth in a number of ways including economies of scale on account of larger international markets for goods, production and demand linkages, increased efficiency and productivity because of specialization, generating employment opportunities within various sectors and industries, learning effects and development of human capital and embracing advanced technologies embodied in foreign capital goods (Basu et al, 2000) and (Were et al, 2002).

A number of studies have been conducted to validate the export led growth proposition in an attempt to provide policy recommendations geared towards enhancing growth of exports and subsequently economic growth of countries. Despite the numerous studies on this subject, no definite conclusive evidence has yet been reached on the causality: Does export growth lead to economic growth or does economic growth lead to export growth? The mixed results could be attributed to among other factors: different characteristics for various countries and their experiences, different variables used, different econometric analysis methods and different time frames applied in various studies.

This study builds on the above to come up with a time frame that encompasses export promotion strategies executed in Kenya and adopts a simple but a comprehensive methodology on the analysis of contribution of exports to economic growth, with the aid of modern time 
series analytical techniques. In so doing, it is expected that the output from this study will be relied upon to offer a solution to developed study gaps and thereby form a solid foundation for sound economic policies on exports and economic growth.

This research investigates the Export Led Growth Hypothesis for Kenya by examining the export data over the sample period. Specifically the study seeks to; examine the contribution of exports to economic growth in Kenya, determine the direction of causality between exports and economic growth and finally make appropriate policy recommendations based on the results.

The rest of this research paper is organized as follows: Section 2 reviews the relevant theoretical and empirical literature in the export growth literature; the methodology, data type and sources used is presented in Section 3 while Section 4 presents the empirical results and discussion of the findings. Finally, Section 5 concludes and offers some policy recommendations.

\section{Export Led Growth Hypothesis}

Arguments for trade were advocated by Mercantilists during the sixteenth to eighteenth century and later by the classical economists- Adam Smith, David Ricardo, Torrens, James Mill and John Stuart Mill. According to mercantilists, a country prospered or became rich by exporting more and importing less. They recommended that imports be restricted and exports be promoted so as to accumulate precious metals of silver and gold hence increase growth and wealth in the country. In order to encourage exports and make them competitive in the international market, they advocated for reduction in taxes, low wages and interest rates of a country.

However the mercantilist ideas were contested by Adam Smith arguing that the wealth of a nation would be increased through increasing productive capacity in an environment where people are free to pursue self interest. This was the advent of Absolute Advantage Theory. A nation has absolute advantage over the other if it uses lesser amount of factors of production to produce one unit of a commodity than the other country. He applied his ideas to specialization and exchange between countries and demonstrated that countries could gain by trading if they have differences in absolute advantage.

David Ricardo did not object Smith's analysis but demonstrated that countries can gain from trade even if one of them is more productive than others in all lines of production so long as one country is not equally less productive in all lines of production. This is what he called Comparative Advantage Theory. Each country has a comparative advantage over its trading partner in the production of a good if the opportunity cost of producing that good is lower at home than in the other country. The gains from trade may be explained by comparing the terms of trade in a closed economy and terms of trade in an open economy.
Heckscher and Ohlin of the H-O-S theory explain the reason why countries have different opportunity costs of producing goods. The source of comparative advantage is the difference in factor endowments between countries and this causes trade between trading partners. The factor endowment is measured in terms of factor prices and in terms of the physical amount of the factors. The argument of the model is that production of export goods that utilize intensively its factors of production that are plentiful and importation of goods that intensively uses scarce factor of production induces more growth.

Demand for exports has a vital role in economic growth as shown by Kaldor's Export-Led Growth model. He asserts that the level and rate of output growth depends on the level and the rate of exports growth. He denotes the dependency of output on exports using the foreign trade multiplier $Y=\frac{1}{\mathrm{~m}} X$ where $(Y)$ the level of output is the multiple of $(X)$ the exogenous level of exports and $(m)$ the reciprocal of the propensity to import (Antonella Palumbo, 2003). In a state of balanced trade, a rise in the level of exports increases the output level through the Keynesian multiplier creating a trade surplus. The increase in output attracts more net investment subsequently growing more output and consumption. In the long run foreign trade becomes newly balanced at a higher level of productivity.

Countries participate in international trade because of differences in factor endowments, technology, production lines and patterns. Bernard and Jensen (1995) undertook a study to establish the role of exporters in the US manufacturing sector at the plant or firm level. Using large cross-sectional data on manufacturing plants they focused on differences at industry level to determine their importance in terms of volume of exports, employment and wages. The results showed that the exporters are important in productivity, creation of employment, absorption of international modern technology and thus boosts productivity and output growth. Exporters also pay higher wages. They also found that plants that export exhibit more growth specifically exporting firms benefit from learning, competition, economies of scale and exposure to ideas, foreign customers and markets. They however demonstrated that exports are a result of successful firm performance but not a measure of future success in productivity growth.

In sectors that produce conventional goods with little learning and technology, free trade may make countries specialize based on their comparative advantages which may reduce long run growth. This is the infant industry argument, the basis of import substituting policy that hurt growth in Africa (Bigsten, 2002). The high levels of tariff and protection have lead to inefficiency and corruption. The long term impact of trade reforms towards export oriented activities is capital formation, foreign investment and economic growth. However, it concluded that other aspects of the economy have to be considered before opening up.

Manufacturing sector is important for African economic growth. Inter-country differences in institutional framework 
and business climate generates comparative advantage mostly felt in manufacturing sector which relies on logistics, regulation and infrastructure that may hinder a firm from supplying goods for export competitively (Bigsten and Söderbom, 2010). A policy framework supporting export production by the manufacturing firms through tax exemptions, subsidies and EPZ may improve their competitiveness and growth hence generate employment, technological progress and reduce vulnerability to weather shocks. They however concluded that African manufacturing firms may not have comparative advantage because of poor economic conditions and even when comparative advantage is present economies may not be able to shift because of low investment.

\subsection{Empirical Literature}

Michaely (1977) and Balassa (1978) used OLS and the Spearman's rank correlation to test the relationship between exports and GNP per capita growth and the results concurred with the export promotion hypothesis. Fajana (1979) similarly obtained findings that supported export led growth hypothesis in a study conducted in Nigeria.

The results for time series data covering 1950-1981 for 37 LDC'S obtained by Jung and Marshall (1985) did not support the export led economic growth in 33 countries except in Egypt, Costa Rica, Indonesia and Ecuador. They used OLS and Granger causality test to estimate real GDP or real GNP, real exports growth, lagged GNP and lagged GDP growth.

Cross country studies by Ram (1987) and Fosu (1990) set out to examine the causal relationship between real exports growth and real GDP growth for 28 African counties and 38 countries including Fiji respectively. The variables estimated included real GDP, real exports, labor force and Gross Domestic Investment share for crosssectional data. Exports had a positive and significant effect on economic growth in both studies hence export led growth hypothesis was supported.

Additionally, Ukpolo (1994) did a study of 8 African LDC's namely Kenya, Tanzania, Congo, Morocco, Nigeria, Senegal, Sierra Leone, and Togo over the period 1969-1988. Using time series data for each of the countries, real GDP was regressed on manufactured exports and nonmanufactured exports. The findings showed a unidirectional causality running from non-manufactured exports to output.

The existence of cointegration and causality from exports to growth in the cases of Israel and Turkey was found using Engle Granger cointegration and causality tests based on Error Correction Model for the period 1953-1991 in a study done by Dutt and Ghosh (1994).

Reizman et al (1995) investigated the export-led growth hypothesis for 126 countries from 1950-1990 by estimating bivariate, trivariate and 5-variable models. The variables included were real GDP, real exports, real imports, primary school enrolment and investment as a share of output. In the estimation of the bivariate model, exports growth
Granger cause real GDP growth in 65 countries. However the results of the trivariate model that included imports supported the ELG hypothesis in only 30 countries while in 25 other countries GDP growth Granger cause exports. The limitation of the study is the unavailability of annual data on primary school enrolment hence it had to be estimated for most years in most countries since the data was only available after every 5 years.

Country studies like one in Costa Rica conducted by Smith (2001) using modern time series econometric techniques such as Engle and Granger 2 step procedure, Johansen Maximum Likelihood and ECM ascertained that exports had a positive and significant effect on economic growth in Costa Rica for the period 1950-1997. The study estimated an augmented Cobb-Douglas production function that included exports of goods and services hence incorporated a broad measure of externalities and productivity gains generated by this sector which stimulated the domestic economy. Population, Gross Domestic Investment and Gross Fixed Capital Formation were also found to determine economic growth for Costa Rica.

The empirical finding of a study examining the association of exports and economic growth in India, Malaysia, Pakistan, Thailand and the Philippines was undertaken by Vohra (2001). Time series data from 19731993 was used to estimate two models, one in an export sector only and the other when both export and non-export sectors exist. The variables estimated are labor, capital and exports. No long run relationship between exports and economic growth was detected but in the short run, exports promoted economic growth especially for middle income countries.

A study carried out in Pakistan by Shirazi (2004) used annual data for 1960-2003 to determine the existence of a relationship between exports, economic growth and any long-run equilibrium among real exports, real imports and real GDP using modern time series regression methods of Engle and Granger, Johansen Maximum Likelihood and Granger causality. The findings revealed a unidirectional relationship that runs from exports to output but no correlation between exports and imports.

The export output relationship in Bangladesh over the period 1976-2003 was determined using quarterly time series data on industrial production index, exports of goods and services and exports of goods only (Al Mamun and Nath, 2005). The ECM and Engle and Granger procedures are used to test the long run equilibrium between industrial production and exports. No short run relationship exists between industrial production and exports but in the long run exports cause growth. The limitation of this study is the unavailability of quarterly GDP data hence the use of industrial production index.

Keong, Yusop and Sen (2005) looked into the export output growth relation in Malaysian time series data over the period 1959-2000. Modern time series analysis techniques of 2-stage least squares, Johansen \& Juselius 
Maximum Likelihood, ECM and Granger causality were used to test any existing long run and short run equilibrium among the variables estimated which were real GDP, real exports, real imports of consumption goods, Gross Fixed Capital Formation, population and exchange rate. All variables other than exchange rate granger caused economic growth hence export led growth was supported in the Malaysian economy.

Musonda (2007) examined the direction of export output growth hypothesis in Zambia over time series data for 1970-2003. Time series analysis techniques of Johansen \& Juselius Maximum Likelihood, ECM and Wald restriction were used to test for long run and short run causality between exports and economic growth. The variables estimated were real GDP, real exports, real imports, real Gross Fixed Capital Formation, skilled and unskilled labor force, real exchange rate, terms of trade and degree of openness. A long run bi-directional causality running from exports to economic growth and economic growth to exports was found. The limitation of the study was the unavailability of labor force data hence the use of population data.

A country study of the causality between exports and economic growth in Namibia was undertaken by Jordaan and Eita (2007) covering 1970-2005. They estimated exports, GDP and GDP per capita and also exports, imports and GDP per capita using Granger causality, Johansen Maximum Likelihood and ECM. It was seen that exports cause GDP and GDP per capita but imports do not cause GDP per capita. They also found that exports, imports and GDP are cointegrated and a bi-directional causality exists between exports and imports.

A study for Kenya undertaken by Mohan and Nandwa (2007) tested for short run and long run relationship between exports and GDP growth and between exports and imports using annual time series data for 1970-2004. Other variables included the exchange rate, labor force and a dummy variable signifying the 1985 economic liberalization period in Kenya. The time series techniques used included Autoregressive Distributed Lag (ARDL), Vector Error Correction Model, Granger causality and Wald restriction. They found a long run unidirectional causality running from exports to GDP growth hence export led growth hypothesis was supported and export enhancing policies were recommended for promotion of growth.

\section{Methodology}

\subsection{Introduction}

This Section presents the theoretical framework of the model adopted for the study, the empirical model established, definitions and measurement of the variables, data types and sources.

\subsection{Theoretical Framework}

The study adopts its framework from a simple national income identity and links it to the study variables. The framework uses an accounting identity that linked output of a nation to the contributing factors.

$$
Y=C+I+G+X-M
$$

Where:

$Y=$ Output level taken as GDP in the study

$C=$ Private Consumption and Government Consumption expenditures

$I=$ Private and Public Investments

$G=$ Government spending

$X=$ Exports

$M=$ Imports

The application of the above function to study variables requires equation $(i)$ rewritten to $(i i)$

$$
Y=\sum_{i=0}^{n} V+\varepsilon
$$

Where:

$Y=$ Output level taken as GDP in the study

$V=$ Vector of factors that affect growth of output estimated in the model

$\mathcal{E}=$ error term represents other factors not included in the model

$i=0,1, \ldots, \mathrm{n}$ indicates the number of independent variables used in the model

To capture the contribution of independent variables to growth of output, we differentiated equation (ii) with respect to the regressors to obtain the equation below:

$$
\dot{Y}=\sum_{i=0}^{n} \dot{V}+\varepsilon
$$

Since $V$ is a vector of independent variables, equation (iv) represents the contribution of various variables to growth.

$$
Y_{t}=\beta_{0}+\beta_{i} V_{t}+\varepsilon_{t}
$$

Where: $i=1,2,3,4, \ldots, n$ represents the number of variables in the vector $V$

The constant term $\left(\beta_{0}\right)$ captures the output that does not depend on the factors under consideration in the study. $\left(\beta_{i}\right)$ represents the individual contribution of factors to growth of output.

\subsection{The Empirical Model under Estimation}

The empirical model is specified as follows:

$$
G D P=f(\stackrel{+}{E X} P, \stackrel{-}{\mathrm{IM} P}, \stackrel{+}{H C}, \stackrel{+}{G C}, \stackrel{+}{\mathrm{H}} \mathrm{V}, \stackrel{+}{F} \stackrel{+}{\mathrm{H} I}, \varepsilon)
$$

Where:

GDP $=$ Real Gross Domestic Product
$\mathrm{EXP}=$ Real exports

$\mathrm{IMP}=$ Real imports 
$\mathrm{HC}=$ Real Household Consumption expenditure

$\mathrm{GC}=$ Real Government Consumption expenditure

$\mathrm{INV}=$ Real Investment measured by Gross Fixed Capital Formation
FDI $=$ Foreign Direct Investment

$\varepsilon=$ error term captures other factors that explain real GDP not included in the model

The model estimated was defined explicitly as follows:

$$
G D P_{t}=\beta_{0}+\beta_{1} E X P_{t}+\beta_{2} I M P_{t}+\beta_{3} H C_{t}+\beta_{4} G C_{t}+\beta_{5} I N V_{t}+\beta_{6} F D I_{t}+\varepsilon_{t}
$$

The variables are as defined in (i) above.

Table 1. Definition of Variables, Measurement and Expected Signs

\begin{tabular}{lll}
\hline Variables & Definition and Measurement & Expected Sign \\
\hline$G D P_{t}$ & Real GDP for each year $t$. It is the value of goods and services produced in Kenya. & $\beta_{0}>0$ \\
$E X P_{t}$ & Real exports for each year $t$. It is the value of exported goods and services. & $\beta_{1}>0$ \\
$I M P_{t}$ & Real imports for each year $t$. It is the value of imported goods and services. & $\beta_{2}<0$ \\
$H C_{t}$ & Real Household Consumption for each year $t$. It includes expenditure on food and beverages, & $\beta_{3}>0$ \\
& clothing and footwear, housing (rent) and consumption in other goods and services. & \\
$G C_{t}$ & Real Government Consumption for each year $t$. It includes expenditure on compensation of & $\beta_{4}>0$ \\
& employees and use of goods and services such as fuel, water, electricity. & \\
$I N V_{t}$ & Real investment for each year $t$. It is proxied by Gross Fixed Capital Formation which & $\beta_{5}>0$ \\
$F D I_{t}$ & includes the value of buildings and structures, transport equipment, other machinery and & $\beta_{6}>0$ \\
\hline
\end{tabular}

\subsection{Data Type and Sources}

The study used annual time series data for the period 1976 to 2011. The data was extracted from the Economic Surveys published by the Kenya National Bureau of Statistics (KNBS). Table 1 provides definition of variables, their measurements and expected signs.

The data was analyzed by use of Eviews Statistical software. The time series data collected was organized and examined for cleanup purpose including identifying any outliers. This entailed examination of the descriptive statistics. Table 2 gives summary of the descriptive statistics of the data used in the study.

The unit roots of the time series variables were tested

through the Augmented Dickey Fuller (ADF) test and Philip Peron (PP) test. This determined whether time series are stationary I (0) or non-stationary I (1) and their order of integration. This is to eliminate spurious regressions and erroneous inferences. The variables were found to be nonstationary and differencing was applied on the time series for stationarity to be achieved. The results are shown in Table 3. The study employed Granger causality test to determine the direction of causality and then cointegration test was carried out using the ARDL model to determined the long run relationship between the variables.

\subsection{Descriptive Statistics}

Table 2. Definition of Variables, Source and Descriptive Statistics

\begin{tabular}{|c|c|c|c|c|c|c|c|}
\hline Variables & $\begin{array}{l}\text { Definition in Ksh. Million } \\
\text { (Constant prices 2001=100) }\end{array}$ & Source & Mean & Median & Std. Dev & Min & Max \\
\hline LGDP & Real GDP & KNBS & 565602.6 & 367146.0 & 518767.7 & 29072.0 & 1539306.0 \\
\hline LEXP & Real exports & KNBS & 149784.4 & 141571.5 & 135079.9 & 9434.0 & 427123.0 \\
\hline LIMP & Real imports & KNBS & 201007.3 & 127299.5 & 203642.0 & 9232.0 & 695931.0 \\
\hline LHC & Real Household consumption & KNBS & 427216.1 & 230336.0 & 415604.8 & 17909.0 & 1206210.0 \\
\hline LGC & Real Government consumption & KNBS & 87640.81 & 54513.0 & 76704.03 & 5076.0 & 238447.0 \\
\hline LINV & Real investment & KNBS & 93848.33 & 16440.50 & 124749.8 & 5809.0 & 403457.0 \\
\hline LFDI & Real FDI & KNBS & 4110.94 & 638.0 & 9508.41 & 7.0 & 49078.0 \\
\hline
\end{tabular}

From the table 2, the average Real GDP is Ksh.565,602 million with the minimum being Ksh.29,072 million while the maximum is Ksh.1,539,306 million. The standard deviation was equally high at Ksh.518, 767 million. Indeed looking at the dispersion, GDP has grown by 53 times from Ksh.29, 072 million in 1976 to Ksh.1, 539,306 million in 2011.

On average, the Real exports are valued at Ksh.149, 784 million with a standard deviation of Ksh.135, 079 million. The minimum is Ksh.9, 434 million while the maximum is Ksh.427, 123 million. The value of real export of goods and services has grown by 45 times.

On the other hand, the mean Real imports are worth
Ksh.201, 007 million (standard deviation of Ksh.203, 642 million) with the lowest and highest value of imports recorded being Ksh.9, 232 million and Ksh.695, 931 million respectively. In a typical year, the share of imports is larger than that of exports and has grown by 75 times from its lowest of Ksh.9, 232 million.

The Real Household Consumption averages Ksh.427, 216 million while that of Real Government Consumption is smaller at Ksh.87, 640 million. The minimum consumption values are at Ksh.17, 909 million and Ksh.5, 076 million respectively while the maximum consumption values are at Ksh.1, 206, 210 million and Ksh.238, 447 million. The standard deviation at Ksh.415, 604 million for Household 
Consumption is very high compared to Ksh.76, 704 million for Government Consumption.

Real investment computed from Gross Fixed Capital Formation averages at Ksh.93, 848 million annually. The minimum investment is at Ksh.5, 809 million while maximum investment recorded is Ksh.403, 457 million. The standard deviation is relatively high at Ksh.124, 749 million and investment has grown by 70 times. On the other hand, Foreign Direct Investment averages at Ksh.4, 110 million (standard deviation of Ksh.9, 508 million) with a low of Ksh.7 million and a high of Ksh.49, 078 million reported.

\section{Data Analysis, Results and Discussion}

\subsection{Introduction}

In this Section, the empirical results are analyzed and presented. The methods and the findings in line with our a priori expectations and similar findings in this area of study are also discussed.

\subsection{Testing for Unit Root}

Table 3. Augmented Dickey Fuller (ADF) and Phillips Peron (PP) Tests

\begin{tabular}{lllll}
\hline \multirow{2}{*}{ Variables } & ADF & & PP & First Difference \\
\cline { 2 - 5 } & Levels & First Difference & Levels & Conclusion \\
\hline LGDP & 0.955697 & $-4.67319 * * *$ & 0.662524 & $-4.78535 * * *$ \\
LEXP & -1.046 & $-6.07493 * * *$ & -1.1747 & $-6.06159 * * *$ \\
LIMP & -1.623 & $-6.09211 * * *$ & -1.6409 & $-6.11739 * * *$ \\
LHC & 0.645781 & $-5.37407 * * *$ & 0.324481 & $-5.5012 * * *$ \\
LGC & -0.27478 & $-4.21861 * *$ & -0.77157 & $-4.27254 * * *$ \\
LINV & -1.97847 & $-5.97763 * * *$ & -1.96968 & $-6.30681 * * *$ \\
LFDI & $-5.1844 * * *$ & $-5.15632 * * *$ & $-5.1844 * * *$ & $-24.5061 * * *$ \\
\hline
\end{tabular}

$*,(* *),[* * *]$ denote significance at $10 \%,(5) \%$ and $[1] \%$ level respectively (Source: Own computation)

The ADF test provides the tau statistics which are then compared with the critical values namely -4.25 ( $1 \%$ level), -3.54 (at 5\% level) and -3.21 (at $10 \%$ level) to make inferences on the univariate characteristics of our variables. The PP test provides test statistics that confirmed the ADF tests. The PP tests statistics are compared with the critical values which are -4.25 (at $1 \%$ level), -3.55 (at 5\% level) and -3.21 (at $10 \%$ level).
From the ADF and the PP test for unit roots, real GDP, real exports, real imports, government consumption, household consumption and investment are non-stationary and must be differenced once to become stationary and therefore integrated of order 1. FDI on the other hand is stationary at both levels and first difference in the two tests.

\subsection{Testing for Granger Causality}

Table 4. VAR Granger Causality Test

\begin{tabular}{|c|c|c|c|c|c|c|c|}
\hline \multicolumn{4}{|c|}{ Dependent variable: LGDP } & & \multirow{2}{*}{$\begin{array}{l}\text { Dependent variable: } \\
\text { Chi-sq }\end{array}$} & \multicolumn{2}{|l|}{ LEXP } \\
\hline Excluded & Chi-sq & df & Prob. & Excluded & & df & Prob. \\
\hline LEXP & 0.039759 & 1 & 0.8420 & LGDP & 0.936948 & 1 & 0.3331 \\
\hline LIMP & 1.242101 & 1 & 0.2651 & LIMP & 2.511913 & 1 & 0.1130 \\
\hline LHC & 0.782454 & 1 & 0.3764 & LHC & 5.359546 & 1 & 0.0206 \\
\hline LGC & 1.596553 & 1 & 0.2064 & LGC & 8.862184 & 1 & 0.0029 \\
\hline LINV & 16.00305 & 1 & 0.0001 & LINV & 6.944593 & 1 & 0.0084 \\
\hline LFDI & 0.011734 & 1 & 0.9137 & LFDI & 0.001647 & 1 & 0.9676 \\
\hline All & 32.30217 & 6 & 0.0000 & All & 19.92326 & 6 & 0.0029 \\
\hline \multicolumn{5}{|c|}{ Dependent variable: LIMP } & Dependent variable: & LHC & \\
\hline Excluded & Chi-sq & $\mathrm{df}$ & Prob. & Excluded & Chi-sq & df & Prob. \\
\hline LGDP & 0.847630 & 1 & 0.3572 & LGDP & 0.665733 & 1 & 0.4145 \\
\hline LEXP & 0.416856 & 1 & 0.5185 & LEXP & 0.594833 & 1 & 0.4406 \\
\hline LHC & 1.267581 & 1 & 0.2602 & LIMP & 0.004662 & 1 & 0.9456 \\
\hline LGC & 4.198951 & 1 & 0.0404 & LGC & 0.540273 & 1 & 0.4623 \\
\hline LINV & 1.466168 & 1 & 0.2260 & LINV & 4.590786 & 1 & 0.0321 \\
\hline LFDI & 0.624486 & 1 & 0.4294 & LFDI & 0.189690 & 1 & 0.6632 \\
\hline All & 18.92772 & 6 & 0.0043 & All & 32.66802 & 6 & 0.0000 \\
\hline \multicolumn{5}{|c|}{ Dependent variable: LGC } & Dependent variable: & LINV & \\
\hline Excluded & Chi-sq & $\mathrm{df}$ & Prob. & Excluded & Chi-sq & df & Prob. \\
\hline LGDP & 2.445046 & 1 & 0.1179 & LGDP & 0.900325 & 1 & 0.3427 \\
\hline LEXP & 0.979806 & 1 & 0.3222 & LEXP & 0.193736 & 1 & 0.6598 \\
\hline LIMP & 0.226115 & 1 & 0.6344 & LIMP & 0.037011 & 1 & 0.8474 \\
\hline LHC & 0.891942 & 1 & 0.3450 & LHC & 0.120931 & 1 & 0.7280 \\
\hline LINV & 21.78147 & 1 & 0.0000 & LGC & 1.159096 & 1 & 0.2817 \\
\hline LFDI & 0.165594 & 1 & 0.6841 & LFDI & 0.683762 & 1 & 0.4083 \\
\hline All & 41.76295 & 6 & 0.0000 & All & 6.127239 & 6 & 0.4091 \\
\hline \multicolumn{8}{|c|}{ Dependent variable: LFDI } \\
\hline Excluded & Chi-sq & $\mathrm{df}$ & Prob. & & & & \\
\hline
\end{tabular}




\begin{tabular}{llll}
\hline LGDP & 0.308476 & 1 & 0.5786 \\
LEXP & 0.087187 & 1 & 0.7678 \\
LIMP & 1.292677 & 1 & 0.2556 \\
LHC & 0.104844 & 1 & 0.7461 \\
LGC & 0.000201 & 1 & 0.9887 \\
LINV & 2.088666 & 1 & 0.1484 \\
All & 19.64552 & 6 & 0.0032 \\
\hline
\end{tabular}

Source: Own computation

Granger causality test helps us identify the causal linkages between the variables. It specifies the null hypothesis that the independent variables granger cause the dependent variable against the alternative they do not granger cause. The decision is on whether or not to reject the null hypothesis based on the $t$ statistics or the $\mathrm{p}$ - values. In this study we reject the null hypothesis that the independent variables granger cause the dependent variable if the $\mathrm{p}$-value is smaller than 5 percent $(\mathrm{p}<0.05)$.

From Table 4, the null hypothesis that exports granger cause GDP will be accepted while GDP does not granger cause exports. The causality is unidirectional running from exports to GDP. Imports do not granger cause GDP, while GDP granger causes imports. In this case there is unidirectional causality running from GDP to imports. However there is a bi-directional causality between household consumption and GDP. Further from the results, there is unidirectional causality running from government consumption and FDI to GDP. Investment does not granger cause GDP but GDP granger causes investment. This means there is unidirectional causality running from GDP to investment.

In addition, there is unidirectional causality running from: exports to imports, exports to household consumption, exports to government consumption and exports to investment. However there is a bi-directional causality between exports and FDI.

\subsection{Auto Regressive Distributed Lag (ARDL)}

It involves simultaneous estimation of the long and short term parameters and is based on unrestricted error correction Auto Regressive Distributed Lag (ARDL) model From the ARDL below, the adjusted $\mathrm{R}$ squared equivalent to 0.94 indicates that the data provides a very good fit for our data since it explains $94 \%$ of the GDP variation. Prior to interpretation of the model we conduct diagnostic tests to confirm the assumption that the residuals are normally distributed with a constant variance. The Jarcque Bera Test is used to test for the normality of the residuals. It utilizes the mean based coefficient of skewness and kurtosis to check normality. If the p-value is less than JB chi-square at $5 \%$ level of significance the null hypothesis is rejected. In addition, tests for serial correlation, heteroskedasticity and misspecification are also done. All the tests are passed. However on account of endogeneity problem of the variables involved, Two Stage Least Squares regression is carried out to solve the problem.

\subsection{Two Stage Least Squares (2SLS)}

Endogeneity occurs if the regressors are highly correlated with the error term either because of an omitted variable, measurement error, or simultaneity and reverse causality. In our model, endogeneity between output and exports as well as openness could exist and hence TwoStage Least Squares regression was used to control for it and get better estimates. This meant that valid instrumental variables were needed. Statistically insignificant variables like Government Consumption and FDI are removed from the model. Therefore, 2-Stage Least Squares with the lagged independent variables of exports, openness, household consumption and investment as the instruments is performed to control for the endogeneity problem.

Table 5. Auto Regressive Distributed Lag Model

\begin{tabular}{|c|c|c|c|c|}
\hline \multicolumn{5}{|l|}{ Dependent Variable: D(LGDP) } \\
\hline \multicolumn{5}{|l|}{ Method: Least Squares } \\
\hline \multicolumn{5}{|l|}{ Sample (adjusted): 19802011} \\
\hline \multicolumn{5}{|l|}{ Included observations: 32 after adjustments } \\
\hline Variable & Coefficient & Std. Error & t-Statistic & Prob. \\
\hline $\mathrm{C}$ & 0.051940 & 0.011411 & 4.551791 & 0.0001 \\
\hline LGDP(-1)-1.91*LOPEN(-1)+2.154*LINV(-1)-13.37 & -0.011482 & 0.002648 & -4.336957 & 0.0002 \\
\hline $\mathrm{D}(\mathrm{LGC}(-2))$ & -0.100547 & 0.056035 & -1.794358 & 0.0844 \\
\hline $\mathrm{D}(\mathrm{LFDI}(-3))$ & 0.000207 & 0.001772 & 0.116776 & 0.9079 \\
\hline $\mathrm{D}(\mathrm{LEXP})$ & 0.137120 & 0.023467 & 5.843159 & 0.0000 \\
\hline $\mathrm{D}(\mathrm{LHC})$ & 0.464133 & 0.054047 & 8.587565 & 0.0000 \\
\hline R-squared & 0.950416 & \multicolumn{2}{|c|}{ Mean dependent var } & 0.110086 \\
\hline Adjusted R-squared & 0.940881 & \multicolumn{2}{|c|}{ S.D. dependent var } & 0.063388 \\
\hline S.E. of regression & 0.015412 & \multicolumn{2}{|c|}{ Akaike info criterion } & -5.339929 \\
\hline Sum squared resid & 0.006176 & \multicolumn{2}{|c|}{ Schwarz criterion } & -5.065104 \\
\hline Log likelihood & 91.43887 & \multicolumn{2}{|c|}{ Hannan-Quinn criter. } & -5.248833 \\
\hline F-statistic & 99.67268 & \multicolumn{2}{|c|}{ Durbin-Watson stat } & 2.619767 \\
\hline Prob(F-statistic) & 0.000000 & & & \\
\hline
\end{tabular}


Table 6. Two Stage Least Squares

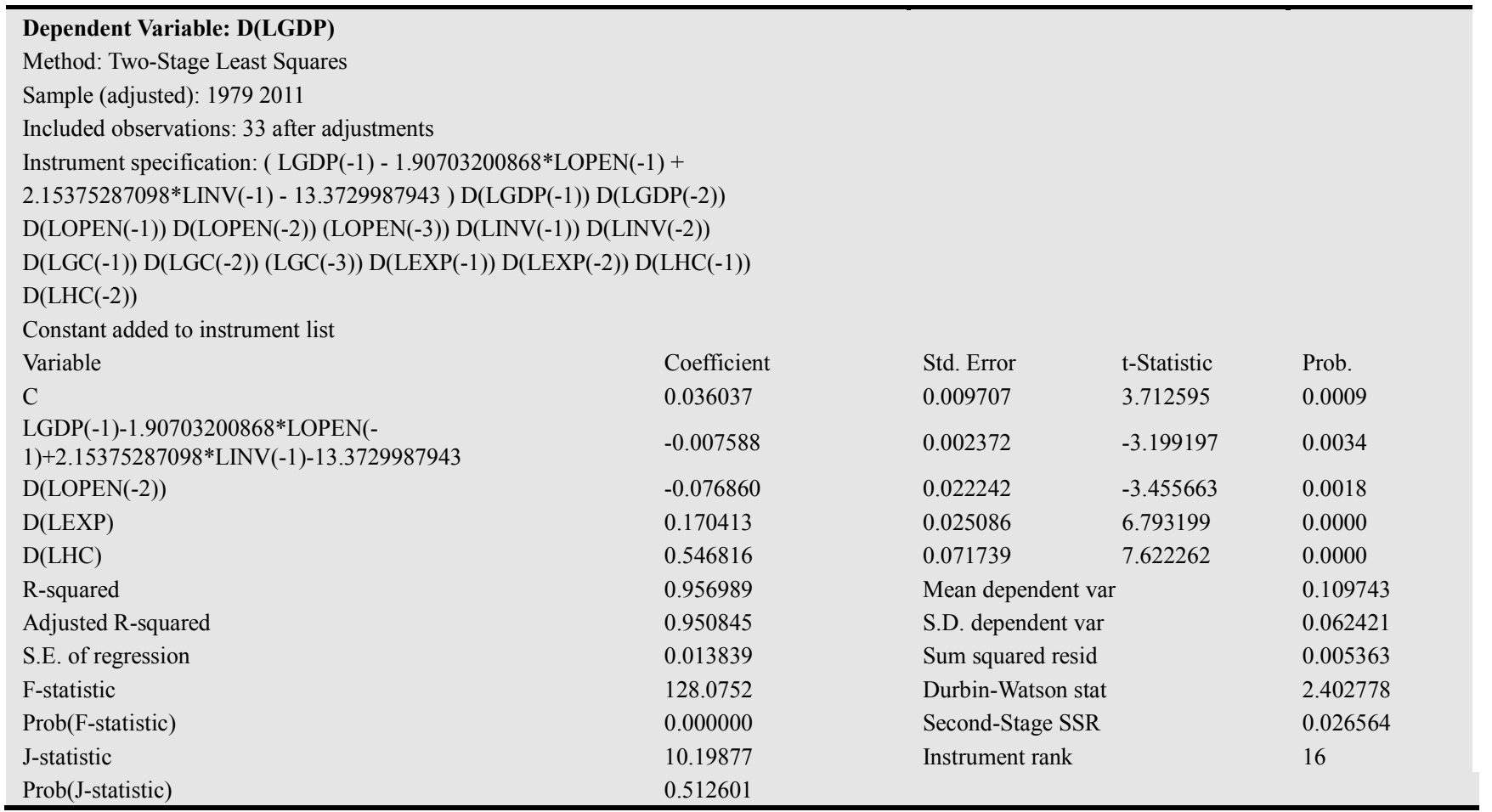

Table 6 presents the results of the short run model obtained using the Two Stage Least Squares. This method was used to solve the problem of endogeneity between output, exports and openness. From the adjusted R-squared of 0.95 and standard error of regression of 0.013 , the model is superior in terms of presenting a good fit for the data since most variables are statistically significant contributors to GDP and also explain a larger percentage of the variations in GDP. We find that all the explanatory variables in first difference are statistically significant for both in the lag and in levels. The estimated error term has a correct sign and is statistically significant at $1 \%$ level. However, the speed of adjustment to long-run changes is quite low (0.0076). The model passed all the diagnostic tests which means there is no evidence of serial correlation, heteroskedasticity and specification. The data was also found to have a normal distribution .

\subsection{Discussion}

The objective of the study was to test the Export Led Growth Hypothesis for Kenya. Using time series data for the period 1976 to 2011, a multiple regression of Real Exports, Real Imports, Real Household Consumption, Real Government Consumption, Real Investment and Real FDI on Real GDP was undertaken.

The 2SLS regression results show that all the variables have the expected signs. The study yields an adjusted Rsquared of 0.95 which means that $95 \%$ of the variation in GDP can be explained by changes in exports, openness, household consumption and investment while the other factors not included in the model account for $5 \%$.

Real Exports has a positive and statistically significant short run relationship with real GDP. This relationship is statistically significant at $1 \%$ level in explaining GDP growth. A $1 \%$ increase in real exports leads to $0.17 \%$ increase in real GDP. The results indicate that the causality is unidirectional running from exports to economic growth. This finding is similar to the finding by Mohan and Nandwa (2007) who found both short run and long run unidirectional relationship from exports to GDP growth. The results are also in line with theoretical literature in which exports are said to be a significant catalyst in boosting economic growth by increasing foreign exchange earnings, promoting expansion and development of industries and encouraging research and development in order to diversify products.

Openness measured as the average of real exports and real imports has a negative short run and long run relationship with real GDP and is statistically significant at $1 \%$ level in explaining GDP growth. A $1 \%$ increase in openness leads to a decrease in real GDP by $0.076 \%$ in the short run and in the long run GDP decreases by $1.9 \%$. This is because the share of imports in Kenya's trade data is large compared to exports (See Table 2). The results also indicate that imports do not granger cause economic growth but economic growth granger causes imports. Increased imports negate balance of payment and thus reduce growth. Imports have been used as one of the macroeconomic variables that may have an effect on the export-economic growth linkage. This is based on the argument of Riezman et al (1995) that imports are crucial in testing the ExportLed Growth hypothesis in order to avoid producing a spurious causality results.

Real household consumption has a positive and 
statistically significant short run relationship with real GDP. This relationship is statistically significant at $1 \%$ level in explaining GDP growth. A $1 \%$ increase in household consumption leads to $0.55 \%$ increase in real GDP. The results also indicate that there is a bi-directional causality between household consumption and economic growth. The Keynesian macroeconomic model argues that domestic demand plays an important role in influencing economic growth by stimulating aggregate expenditure. Household consumption is a significant contributor to real GDP as it promotes productivity by firms to fill the household demand. It creates demand for goods and services, a contributory factor to industrial production and economic activities.

Real investment has a positive and statistically significant long run relationship with real GDP. This is statistically significant at $1 \%$ level in explaining GDP growth. A $1 \%$ increase in real investment leads to a $2.2 \%$ increase in real GDP. Physical capital accumulation is a major source of economic growth in all countries. The results show that it is the most significant contributor to economic growth among the variables studied with $2.2 \%$. In the Harrod-Domar economic growth theory, a country needs to replace worn-out capital goods such as structures and buildings, equipment and machinery hence they must retain a proportion of their national income as well as increase new investments for the economy to grow. The neoclassical theory says that an increase in capital as an input in production leads to increases in output.

The results from the model also show that there is unidirectional causality running from exports to imports, exports to household consumption, exports to government consumption and exports to investment. This means increase in exports leads to an increase in consumption and investment which through the multiplier effect leads to higher growth.

The analysis encountered endogeneity between the variables exports, openness, household consumption and GDP. This was dealt with using 2SLS regression with lagged variables of independent variables as instruments to produce unbiased results.

\section{Summary, Conclusions and Policy Recommendations}

\subsection{Summary and Conclusion}

The main objective of this paper was to investigate the Export Led Growth Hypothesis in Kenya while controlling for other potentially relevant variables such as imports, consumption, investment and FDI omitted in models of previous studies. Specifically the study assessed whether promoting exports enhances economic growth. This paper implemented the 2-Stage Least Squares techniques in testing the ELGH for Kenya on the basis of time series data from 1976-2011.

The empirical results have shown that the ELGH hypothesis can be verified in Kenya in the short run. The causality is unidirectional running from exports to GDP. Exports granger cause GDP indicating that they have a significant positive effect on GDP in Kenya for the period studied. Economic growth has also been influenced positively by household consumption, government consumption, investment and foreign direct investment.

In the short run, household consumption has a positive effect on GDP however the causality is bi-directional between the two variables. Investment does not granger cause GDP in the short run but in the long run it has a positive significant effect on GDP. Further, there is unidirectional causality running from government consumption and FDI to GDP. Conversely, imports do not granger cause GDP and have a negative effect on GDP in the long run.

These results are in line with other literature in this area such as Smith (2001) and Mohan and Nandwa (2007) among others, whose results supported ELGH.

\subsection{Policy Recommendations}

The study has established that growth in exports promotes economic growth. Kenya should therefore ensure that the macroeconomic and institutional environment is conducive for export growth specifically the diversification of export commodities, tax rebates on imported inputs for production of exports and export-oriented industries. The country should have solid macroeconomic policies directed towards the export sector.

There are potential export markets that can be explored to Kenya's advantage in economic integration blocks particularly the East African Community and Common Market for Eastern and Southern Africa. Kenya needs to deepen its integration with regional economic blocks to increase its bargaining power and broaden its market.

Exchange rate stability is important as it affects imports, exports and FDI. Exchange rates should be managed to avoid overvaluation of the domestic currency. The stability will make it possible to avoid imposing general import restrictions and facilitate a gradual reduction of trade restrictions. Both trade liberalization and realistic exchange rates are necessary for export sector success. In addition, provision of an adequate infrastructure and technology has a positive impact on exports and FDI and finally on economic growth.

\section{References}

[1] Al Mamun, K.A., and Nath, H.K. (2005), "Export-Led Growth in Bangladesh: A Time Series Analysis", Applied Economics Letters, 12, pp. 361-364.

[2] Balassa, B. (1978), "Exports and Economic Growth: Further Evidence", Journal of Development Economics, 5, 181 - 89.

[3] Basu, A., Calamitsis, E.A., and Ghura, D. (2000), "Promoting Growth in Sub-Saharan Africa: Learning What Works", Economic Issues, 23, Washington, DC: IMF. 
[4] Bernard, A. B., and J. B. Jensen (1995)," Exports, Jobs, Wages in U.S. Manufacturing, 1976-1987", Brookings Papers on Economic Activity, Microeconomics, Washington DC

[5] Bigsten, A. (2002), "Can Africa Catch Up?" World Economics, Vol. 3, No.2

[6] Bigsten, A. and M. Söderbom (2010), “African Firms in the Global Economy", Department of Economics \& Gothenburg Centre of Globalization and Development, University of Gothenburg

[7] Dutt, S. D., and D. Ghosh, (1994), "An Empirical investigation of the Export Growth-Economic Growth relationship", Applied Economics Letters 1: 44-48.

[8] Fajana, O. (1979), "Trade and Growth: The Nigerian Experience", World Development Journal, 7, pp. 73-78.

[9] Fosu, A.K. (1990), "Exports and Economic Growth: The African Case", World Development, Vol. 18, No. 6 pp. 83135.

[10] Johansen, S., and K. Juselius (1990), "Maximum Likelihood Estimation and Inference on Cointegration with Applications to The Demand for Money", Oxford Bulletin of Economics and Statistics 52: 169-211.

[11] Jordaan, A. C., and Eita, J. H. (2007), "Export and Economic Growth in Namibia: A Granger Causality Analysis", South African Journal of Economics, Vol. 75:3.

[12] Jung, W.S., and Marshall, P.J. (1985), "Exports, Growth and Causality in Developing Countries", Journal of Development Economics, Vol. 18, pp. 1-12.

[13] Keong, C.C., Yusop, Z., and Sen, V.L.K (2005), "ExportLed Growth Hypothesis in Malaysia: An Application of Two-Stage Least Square Technique", Sunways Academic Journal, 2, 13-22

[14] Michaely, M. (1977), "Exports and Growth: An Empirical Investigation", Journal of Development Economics, 4, 49 53.

[15] Mohan, R., and Nandwa, B. (2007), “Testing Export-led
Growth Hypothesis in Kenya: An ARDL Bounds Test Approach", Bryant University, pp. 1-18.

[16] Musonda, I. (2007), "Is Economic growth led by Exports in Zambia?" Ministry of Finance and National Planning Planning and Economic Management Lusaka, Zambia, pp.122

[17] Palumbo, A. (2003), "Supply and demand in Kaldor's model of growth", www.aracne-editrice.it

[18] Ram, R. (1987), "Exports and Economic Growth in Developing Countries: Evidence from Time Series and Cross-Sectional Data", Journal of Economic Development and Change, 36, pp. 51-72.

[19] Republic of Kenya, Economic Surveys, Various Editions

[20] Riezman, R. G., Summers, P.M., and Whiteman, C. H. (1995), "The Engine of Growth or Its Handmaiden? A TimeSeries Assessment of Export-Led Growth", Empirical Economics, 21, 77-110

[21] Shirazi, N. S., and Manap, T.A.A. (2004), "Exports and Economic Growth Nexus: The Case of Pakistan", Pakistan Development Review, 43: 4 Part II (Winter 2004) pp. 563581

[22] Smith, E.J.M. (2001), "Is Export Led Growth Hypothesis Valid for Developing Countries? A Case Study of Costa Rica", UNCTAD: Policy Issues in International Trade and Commodities Study Series No.7;UNCTAD/ITCD/TAB/8; United Nations Publications, Geneva.

[23] Ukpolo, V. (1994): "Export Composition and Growth of Selected Low-Income African Countries: Evidence from Time-Series Data," Applied Economics 26, 445-449.

[24] Vohra, R. (2001), "Export and Economic Growth: Further Time Series Evidence from Less Developed Countries", International Advances in Economic Research, Vol. 7

[25] Were, M., Ndungu, N.S., Geda, A., and Karingi, S.N. (2002) "Analysis of Kenya's Export Performance: An Empirical Evaluation", KIPPRA Discussion Paper No. 22, November 2002 Kenya Institute for Public Policy Research and Analysis, Nairobi, Kenya. 